\title{
Characterization of The Nutritional Properties of Sorghum Composite Flours Using Different Food to Food Fortification Approaches
}

\author{
Violet K.-Mugalavai, Josiah O. Oyalo and Augustino O. Onkware
}

\begin{abstract}
Intervention using blended composite flours can reduce malnutrition in sub Saharan Africa. Prevalence of protein-energy malnutrition among the vulnerable children has necessitated research on cost effective food product development like food to food fortification of common staples like sorghum. An investigation was carried out on the nutritional properties of selected sorghum composite flours for the production of porridge for both home and industrial applications. In this study, composite flours V1 to V4 were made from sorghum, maize, grain amaranth, baobab and butternut at different rations; V1-(42.5:22.5:5:15:15),V2-(22.5:42.5:5:15:15), V3-(32.5:32.5:5:15:15) and V4-(65:0:5:15:15) were compared against composite flours AV1 to AV4 made from sorghum, cassava, chickpea, orange fleshed sweet potatoes (OFSP) and baobab; AV1-(42.5:22.5:5:15:15) AV2-(22.5:42.5:5:15:15), AV3-(32.5:32.5:5:15:15) and AV4-(65:0:5:15:15). Standard methods were used in determining the chemical characteristics of the composite flours. Composite flour formulations were based on Concept $4{ }^{\circledR}$ creative software. Results on proximate composition indicated a significant $(p<0.05)$ difference in moisture content of the control composite (V5) and the other composite flours with the moisture content ranging from $9.1 \%$ to $12.1 \%$ in $\mathrm{V} 5$ and $\mathrm{V3}$ respectively. Carbohydrates were the most abundant nutrient in the composite flours 66.0 to $72.7 \%$ in V1 and V5 respectively, followed by fat $5.5 \%$ (AV3) to $9.2 \%$ (AV1), protein 5.1 (AV2) to 8.6\% (AV4), crude fibre 1.5 (V2) to 4.3\% (V5), and ash 1.4 (AV1) to $2.8 \%$ (AV4). The total energy ranged between $359.25 \mathrm{kcal}(\mathrm{V} 4)$ to $379.94 \mathrm{kcal}$ (V1) however, these values were not significantly different $(p>0.05)$. Zinc, calcium and magnesium concentration were significantly different $(p<0.05)$ between the sorghum-maize-grain amaranthbaobab-butternut, on one hand and sorghum-cassava-chickpeaOFSP-baobab composite flours on the other. The concentrations of phosphorus and Iron were not significantly different ( $p>$ 0.05). Correlation analysis revealed significant negative correlation between crude protein and fibre $(-0.512, p \leq 0.001)$ and crude protein and iron $(-0.386, p \leq 0.047)$, whereas crude protein and magnesium had a significant positive correlation $(0.455, p \leq 0.017)$. The results indicate that both categories of flour composites have the potential to improve nutritional status of consumers. Thus, consumption of $\mathrm{V} 1$ and $\mathrm{V} 4$ composite flours with a protein content of $8.1 \%$ and $8.6 \%$ maybe encouraged for children aged 6 - 59 months who need products with good nutritional composition for proper growth and development.
\end{abstract}

Index Terms - Wholemeal cereal, Composite flours, Nutritional quality, Food to food fortification.

Published on November 10, 2020

Violet K. Mugalavai, Department of Family and Consumer Sciences, \& Laboratory of Food Processing Training and Incubation Centre, University of Eldoret, Kenya.

(e-mail: violet.mugalavai ${ }^{\circledR}$ gmail.com).

\section{INTRODUCTION}

Sorghum bicolor is a cereal that is used by the world over as a food and feed, among other uses as well. It is an important staple food of the poor in many countries [1]-[3]. However,despite its potential and an important food cereal, sorghum has low nutritional value and inferior organoleptic properties compared to other popular cereals, such as maize and rice [3]. This inferiority is partly because its major storage protein, kafirin, is very poor in essential amino acid, lysine, as well as poor digestibility of kafirins in cooked foods [2]. This has therefore, led to food to food fortification of sorghum flours to improve on the protein quality as well as bioavailability of micronutrients [4].

Most food-to-food fortification combinations are done with legumes; which are rich in lysine, with a cereal that contains a relatively good concentration of sulphurcontaining amino acids results in protein nutritional compensation [5], [6]. Sorghum food based interventions have been applied to reduce malnutrition and nutrition insecurity in Kenyan households as well as other areas in Africa [7] where it mostly consumed as porridge and flatbreads. Flatbreads are widely consumed in Northern Africa, for example the kisra in Sudan [2], [8]. Porridge can be thin (uji) or stiff (ugali). The main difference between ugali and uji relates to the amount of flour that is required to make the products. Less flour (about $10 \% \mathrm{w} / \mathrm{v}$ ) is required to make uji than ugali (about 30\% w/v) [9].

Sorghum is more popular in rural households and amongst the low income urban dwellers in Kenya [7], [10]. The porridges are made from unblended or composites of a variety of flours including sorghum. When the flours are heated in excess water, the starch-rich slurry transforms into porridge as a result of gelatinization of starch [8]-[10]. Infants and young children are given thin porridge as a weaning food, whereas adults consume it as a beverage [8], [11]. It is, also, a source of nourishment for the sick and the invalid. The relevance of adequate nutrition as a foundation for health and development cannot be overemphasized [11].

Formulation and development of nutritious food products from local foods is gaining attention in many developing nations [12]. Traditionally consumed foods tend to have low protein, energy levels and high bulk [7], [12]. This has led to a recurring cycle of malnutrition because the high bulk reduces food intake by the child often resulting in

Josiah O. Oyalo, Institute of Food Bioresources Technology, Dedan Kimathi University of Technology, Kenya.

(e-mail: koyalo.josiah@gmail.com).

Augustino O. Onkware, School of Science, Rongo University, Kenya.

(e-mail: aonkware@yahoo.com). 
undernutrition [13]. Poor nutrition amongst infants and young children leads to retarded growth and increased morbidity and mortality as well as for the adults [14].

Therefore, knowledge of nutritional composition of food made by flour compositing is necessary for planning food demand and supply at the macro as well as at the micro-level, especially during prescription of a dietary approach as well as in determining and correcting the nutritional value of a given product [3]. Flour compositing involves mixing various flours from tubers with cereals or legumes in proper proportions to make economic use of local cultivated crops to produce high quality food products [15]. The qualities of product depend on the proportional composition of the composites and flour properties [16]. The present study was carried out to develop sorghum composite flours and evaluate their nutritional potential for making thin porridge (uji) for household consumption.

\section{MATERIALs AND Methods}

\section{A. General}

The study was conducted at the Food Processing Training and Incubation Centre (FPTIC), University of Eldoret, Kenya. The experimental material comprised of sorghum maize, amaranth flour, butternut, cassava, chickpea and orange fleshed sweet potato. The baobab fruit pulp flour was produced according to the protocol of Mounjouenpou et al. [17].

\section{B. Preparation of the Flours}

Cassava tubers were washed and peeled by hand. They were then cut into small cubes and sun dried to $15 \%$ moisture content, and finely milled. Sorghum, chickpea, and maize were cleaned to remove dusts, broken seeds and other extraneous materials, sun dried to $15 \%$ moisture and then finely milled. The fruit of baobab was carefully pounded in a mortar to avoid breaking the seeds. The pulp thus obtained was subsequently milled and sieved using a $200 \mu \mathrm{m}$ mesh sieve to obtain baobab pulp flour. The method described by Akande, Nakimbugwe and Mukisa [14] was adopted for the processing of the orange-fleshed sweet potatoes (OFSP) and butternuts.

\section{Product Development}

The Concept 4 creative software (Creative Formulation Concepts, LLC, Annapolis, MD, USA) was used to generate two formulations as shown in Table I and Table II, respectively targeting approximate contribution of $90 \%$ protein, 30\% energy, $45 \%$ vitamin $\mathrm{A}$, and $50-70 \%$ minerals of the recommended dietary intake of children below 5 years based on the guidelines by the Institute of Medicine of the National Academics [7], [18]. The composite flour which had maize as an additional cereal were coded V1, V2, V3, and V4 with V5 being the control sample (Table 1). Samples which had cassava and OFSP as an additional starch sources were randomly given codes AV1, AV2, AV3 and AV4. The composite flour samples were packaged in aluminum laminated packages and stored at room temperature $\left(24 \pm 5^{\circ}\right.$ C). The constant percentage of baobab flour at $15 \%$ across all the flour samples was based on a study by Mounjouenpou et al. [17] who noted an improvement in sensory attributes and overall acceptability with baobab flour incorporated composite flours as a partial replacement of sorghum flour within the range of $15-20 \%$.

\section{Characteristics of the Composite Flours \\ 1. Proximate analysis}

Proximate chemical composition analysis of composites flour samples was performed according to AOAC International Official Methods of Analysis (AOAC) [19]. Moisture content was determined by the oven method; fat content was determined by using petroleum ether extraction; protein content was determined by Kjeldahl method (nitrogen content $\times 6.25$ ); and crude fiber was determined by digesting defatted samples with diluted acid $(1.25 \%)$ sulfuric acid solution for $30 \mathrm{~min}$ at boiling point followed by digestion with $1.25 \%$ sodium hydroxide solution for the same duration [20], [21]. Carbohydrate concentration was obtained by the difference between 100 and the total sum of the percentage of moisture, ash, fat, fibre and protein [14], [20], [21].

\begin{tabular}{|c|c|c|c|c|c|}
\hline \multirow{3}{*}{$\begin{array}{l}\text { Ingredients (flour) } \\
\qquad / 100 \mathrm{~g}\end{array}$} & \multicolumn{5}{|c|}{$\begin{array}{c}\text { Proportion }(\%) \text { of the different ingredients in the } \\
\text { composite flour }\end{array}$} \\
\hline & \multicolumn{5}{|c|}{ Samples code } \\
\hline & V1 & $\mathrm{V} 2$ & V3 & V4 & $\begin{array}{c}\mathrm{V} 5 \\
\text { (control) }\end{array}$ \\
\hline Sorghum & 42.5 & 22.5 & 32.5 & 65 & 100 \\
\hline Maize & 22.5 & 42.5 & 32.5 & - & - \\
\hline Grain Amaranth & 5 & 5 & 5 & 5 & - \\
\hline Baobab & 15 & 15 & 15 & 15 & - \\
\hline Butternut & 15 & 15 & 15 & 15 & - \\
\hline
\end{tabular}

* Percentage were based on weight.

TABLE II: DIFFERENT PROPORTIONS (\%) OF SORGHUM, CASSAVA, CHICKPEA, OFSP, AND BAOBAB AND BUTTERNUT USED IN COMPOSITE

\begin{tabular}{ccccc} 
& \multicolumn{4}{c}{ FLOURS } \\
\hline & \multicolumn{3}{c}{$\begin{array}{c}\text { Proportion (\%) of the different } \\
\text { ingredients in the composite flour }\end{array}$} \\
\cline { 2 - 5 } Ingredients (flour) $/ 100 \mathrm{~g}$ & \multicolumn{4}{c}{ Samples code } \\
\cline { 2 - 5 } & AV1 & AV2 & AV3 & AV4 \\
\hline Sorghum & 42.5 & 22.5 & 32.5 & 65 \\
Cassava & 22.5 & 42.5 & 32.5 & - \\
Chickpea & 5 & 5 & 5 & 5 \\
Orange fleshed sweet potato & 15 & 15 & 15 & 15 \\
(OFSP) & 15 & 15 & 15 & 15 \\
Baobab & & & &
\end{tabular}

*Percentage were based on weight.

\section{Determination of energy content}

The total calorie value of each composite flour sample was determined using the Atwater factor method (protein and carbohydrate values were each multiplied by $4 \mathrm{kcal} / \mathrm{g}$, whereas fat values were each multiplied by $9 \mathrm{kcal} / \mathrm{g}$ )-Eq.1 [20].

Calorific Value $(\mathrm{Kcal} / 100 \mathrm{~g})=[(\%$ Protein $\times 4)+$

$(\%$ Carbohydrate $\times 4)+(\%$ Fat $\times 9)]$

\section{Mineral content determination}

Flour samples were analyzed for phosphorus, zinc, iron, calcium and magnesium. Analysis involved the use of atomic absorption spectrophotometer (AAS, Shelton, CT, USA). Standard stock solutions of calcium, zinc, iron and magnesium and were also prepared from AAS grade chemicals by appropriate dilution [20], [22]. Ascorbic acid blue colour procedure was used to obtain total phosphorus 
[22]. Calibration curves were thereafter obtained by plotting the concentration against the absorbance for the calcium, zinc, iron, sodium, and phosphorus measurements. Calibration equations were derived and used to upgrade the apparent concentration to the actual concentration in $\mathrm{mg} / 100$ $\mathrm{g}$. These chemical analyses were performed in triplicate.

\section{E. Data Analysis}

The data obtained was subjected to analysis of variance using SPSS $®$ computer software (v. 20, SPSS Inc., Chicago, IL, USA). Comparisons among means for different groups was done using Tukey honestly significant difference (HSD) test at $p \leq 0.05$. Association between proximate composition and mineral concentration was tested using Pearson's correlation. Experimental results were expressed as means $\underline{ \pm}$ standard deviations (SD).

\section{RESULTS AND DISCUSSION}

\section{A. Nutritional profile of sorghum based composite flours}

The crude protein, crude fat, ash, carbohydrates and crude fibre of sorghum based composite flours on dry weight basis except for moisture content (Table III).

Comparison of V1 and AV1, V2 and AV2, V3 and AV3, V4 and AV4 did not yield any difference in nutrient profile therefore, this discussion cuts across all the samples. The moisture content of the sorghum composite flours ranged from V5 (9.1\%) to V3 (12.1\%). V3 contained more sorghum $(32.5 \%)$ and more maize $(32.5 \%)$ than the control sample; V5 (100\% sorghum). More sorghum and maize refers to high starch content in the flour thus more water adsorption [23]. The moisture content was within the critical moisture (12\%) content for flours and this is attributed to proper drying and handling however, these values were higher than the moisture content $(<5 \%)$ for complementary foods as recommended by Codex Alimentarius Standards [20], [24]. Low moisture content prevents microbial activity thus, extends the shelf life of flour [11]. It also reduces biochemical reactions and thus reduces rancidity. There was no significance difference between the ash content of the sorghum composite flours ( $p$ $>0.05$ ). However, the ash content values were slightly higher than the values recorded by Mabelebele, Gous, Siwela and Iji [25]. This may be due to difference in the mineral content of the different ingredients added to make the sorghum composite flour. The protein content of the various sorghumbased composite flours was significantly different $(p<0.05)$ with values ranging from $5.1 \%$ to $8.6 \%$ in AV2 and AV4 respectively (Table III). This range was similar values recorded by in Dicko et al. [26]. However, protein values for AV1 (5.4\%) and AV2 (5.1\%) were less than the stipulated protein range of $6 \%$ to $15 \%$ for complementary foods for older infants and young children [20], [24]. This finding was similar to previous reports which indicate that sorghum is deficient in a variety of nutrients and, could not supply adequately the required nutrients for rapid growth and development hence there is need to complement it with other products like legumes to enhance its nutritional value [12], [27], [28]. Additionally, low protein availability in the sorghum composite flours may be due to the presence of antinutritional factors, including tannins [28].
There was no significant difference $(\mathrm{p}>0.05)$ in crude fat content between the sorghum composite flours. The introduction of fortificants to sorghum increased the fat content in V1, AV1, V2, AV2 and V3 in comparison to the control V5 while crude fat values for AV3, V4 and AV4 remained within the range of 5.5-5.9\%. Across all the composite flours, fat content ranged between $5.5 \%$ and $9.2 \%$ : these values were higher than the range of $2.7 \%$ to $3.7 \%$ reported by Mabelebele, Gous, Siwela and Iji [25], but similar to those reported by Twinomuhwezi, Mihigo and Awuchi [29]. Lipids are important in the body as energy suppliers and essential components of cell membranes. The increase in lipid content of the composite maybe due to the high oil retention capacity of baobab flour used in all the samples [17]. Moreover, the low-fat range may be suitable for longer storage of the sorghum composite flours in areas with low humidity and high temperature.

There were significant differences in crude fibre contents ( $\mathrm{p}<0.05$ ), with values ranging from $1.5 \%$ to $4.3 \%$ in V2 and both AV2 and V5 respectively. These values were within the range of $3.51 \%$ previously reported by Samarth, More and Imran [30]. The source crude fibre in the various composite was varied: high fibre content recorded in V5 (100\%) is maybe due to the high proportion of sorghum, whereas the similar content in AV2 $22.5 \%$ sorghum $+42.5 \%$ cassava + $5 \%$ chickpea $+15 \%$ baobab $+15 \%$ OFSP) may be due to higher cassava proportion [15] in addition to the sorghum fibre (Table III). Contribution of polyphenols to the lignin fraction of dietary fibre is usually responsible for higher values of dietary fibre in the high tannin varieties of sorghum cultivars [25]. The crude fibre contents were within the limits recommended by codex standards $(5 \%)$ for complementary foods. Thus, the sorghum composite flours are suitable for use in home based complementary feeding of children aged 6-59 months [20].

The carbohydrate content of the sorghum based composite flours showed significant difference ( $p<0.05$ ), with the values ranging from $66.0 \%$ to $72.7 \%$ in V1 and V5 $(100 \%$ sorghum) respectively. These values were within the range of $67.58 \%$ to $73.47 \%$ reported by Marete and Mwasaru [31] whereas Amagloh and Coad [32] reported lower values within the range of 50.25 to $58.92 \%$ for sorghum composited with maize and sweet potatoes. However, the carbohydrate content of the OFSP-based composite flours is within the range (45-65\%) recommended for infant feeding, making it suitable for use in the preparation of porridges for children aged 6-59 months [20], [32].

The difference in the proportion of ingredients used in this study resulted in higher carbohydrate content as reported (Table III). There was no significant difference in energy content among the various sorghum composite flours $(p>$ $0.05)$ (Table III). The relatively high energy content (359.25$379.48 \mathrm{kcal} / 100 \mathrm{~g}$ ) recorded for the flours may be explained by the high fat and carbohydrate content (Table III). The energy contents were approximately half the total energy requirement for children aged $9-11$ months and $894 \mathrm{kcal} /$ day [33]. Therefore, the sorghum composite flours are suitable for thin and thick porridge making for children aged 6-59 month [20] as well as adults who can supplement their diets with other available foods. 
TABLE III: ProXimate (\%) AND ENERgY (KCAL/100 G) COMPOSITION OF SORGHUM BASED COMPOSITE Flours ON DRY WeIGHT BASIS (EXCEPT MOISTURE CONTENT)

\begin{tabular}{|c|c|c|c|c|c|c|c|c|c|c|}
\hline $\begin{array}{c}\text { Samples } \\
\text { Parameter }\end{array}$ & V1 & AV1 & $\mathrm{V} 2$ & AV2 & V3 & AV3 & V4 & AV4 & V5 & $\begin{array}{c}\mathrm{p}- \\
\text { value }\end{array}$ \\
\hline $\begin{array}{c}\text { Moisture } \\
\text { content }\end{array}$ & $11.3 \pm 0.2^{\mathrm{a}, \mathrm{b}}$ & $11.4 \pm 0.5^{\mathrm{a}, \mathrm{b}}$ & $11.0 \pm 0.2^{\mathrm{a}, \mathrm{b}}$ & $10.9 \pm 0.3^{\mathrm{a}, \mathrm{b}}$ & $12.1 \pm 0.5^{\mathrm{a}}$ & $10.7 \pm 0.2^{b}$ & $11.6 \pm 0.5^{\mathrm{a}, \mathrm{b}}$ & $10.7 \pm 0.3^{b}$ & $9.1 \pm 0.9 \mathrm{c}$ & $<0.01$ \\
\hline Ash & $2.2 \pm 1.4^{\mathrm{a}}$ & $1.4 \pm 2.4^{\mathrm{a}}$ & $2.4 \pm 1.9^{\mathrm{a}}$ & $2.0 \pm 2.6^{\mathrm{a}}$ & $2.4 \pm 2.2^{\mathrm{a}}$ & $2.4 \pm 2.7^{\mathrm{a}}$ & $2.7 \pm 2.3^{a}$ & $2.8 \pm 2.8^{\mathrm{a}}$ & $2.6 \pm 2.4^{\mathrm{a}}$ & 0.174 \\
\hline Crude protein & $8.2 \pm 0.4^{\mathrm{a}, \mathrm{b}}$ & $5.4 \pm 0.2^{\mathrm{c}, \mathrm{d}}$ & $7.3 \pm 0.8^{\mathrm{a}, \mathrm{b}, \mathrm{c}, \mathrm{d}}$ & $5.1 \pm 1.3^{\mathrm{d}}$ & $5.92 \pm 0.9^{\mathrm{b}, \mathrm{c}, \mathrm{d}}$ & $7.6 \pm 0.8^{\mathrm{a}, \mathrm{b}, \mathrm{c}}$ & $7.3 \pm \underset{d}{0.8} 8^{a, b, c}$ & $8.6 \pm 0.5^{\mathrm{a}}$ & $5.43 \pm 1.3^{\mathrm{c}, \mathrm{d}}$ & $<0.01$ \\
\hline Crude fat & $9.2 \pm 2.8^{a}$ & $7.9 \pm 0.5^{\mathrm{a}}$ & $7.7 \pm 2.9^{\mathrm{a}}$ & $7.6 \pm 0.8^{a}$ & $6.1 \pm 0.8^{\mathrm{a}}$ & $5.5 \pm 0.5^{\mathrm{a}}$ & $5.9 \pm 0.3^{\mathrm{a}}$ & $5.9 \pm 0.5^{\mathrm{a}}$ & $5.9 \pm 0.7^{\mathrm{a}}$ & 0.064 \\
\hline $\begin{array}{c}\text { Total } \\
\text { carbohydrates }\end{array}$ & $66.0 \pm 2.4^{\mathrm{b}}$ & $70.4 \pm 0.6^{\mathrm{a}, \mathrm{b}}$ & $70.2 \pm 3.3^{\mathrm{a}, \mathrm{b}}$ & $70.1 \pm 2.9^{\mathrm{a}, \mathrm{b}}$ & $70.5 \pm 1.6^{\mathrm{a}, \mathrm{b}}$ & $71.1 \pm 1.3^{\mathrm{a}, \mathrm{b}}$ & $69.2 \pm 0.9^{\mathrm{a}, \mathrm{b}}$ & $69.1 \pm 0.2^{\mathrm{a}, \mathrm{b}}$ & $72.7 \pm 1.5^{\mathrm{a}}$ & 0.04 \\
\hline Crude fibre & $3.2 \pm 0.7^{\mathrm{a}, \mathrm{b}}$ & $3.5 \pm 0.1^{\mathrm{a}}$ & $1.5 \pm 0.3^{\mathrm{b}}$ & $4.3 \pm 1.2^{\mathrm{a}}$ & $3.0 \pm 0.4^{\mathrm{a}, \mathrm{b}}$ & $2.8 \pm 0.9^{\mathrm{a}, \mathrm{b}}$ & $3.4 \pm 0.3^{\mathrm{a}}$ & $2.8 \pm 0.6^{\mathrm{a}, \mathrm{b}}$ & $4.3 \pm 0.3^{a}$ & $<0.01$ \\
\hline Energy & $379.48 \pm 16.7^{\mathrm{a}}$ & $374.52 \pm 4.6^{\mathrm{a}}$ & $378.4 \pm 15.9^{a}$ & $369.57 \pm 5.9^{\mathrm{a}}$ & $360.33 \pm 4.2^{\mathrm{a}}$ & $363.92 \pm 2.8^{a}$ & $359.25 \pm 1.3^{\mathrm{a}}$ & $364.7 \pm 5.3^{\mathrm{a}}$ & $365.2 \pm 3.7^{\mathrm{a}}$ & 0.154 \\
\hline
\end{tabular}

Results are means and standard deviations of triplicate determinations. Means in the same column with different superscripts (a, b, c, d) are significantly $(p<0.05)$ different.

P-phosphorus; Zn-zinc; Fe-iron; Ca-calcium; Mg-magnesium. Values are means and standard deviations of triplicate determinations. Values with different superscript alphabetical letter(s) within the same column show significant differences $(\mathrm{P}<0.05)$, while values with same alphabetical letter(s) within the same column show no-significant differences among mineral composition $(\mathrm{P}<0.05)$. V5-a 100\% sorghum flour was used as the control.

Where -for Table III; V1 $=42.5 \%$ sorghum $+22.5 \%$ maize $+5 \%$ grain amaranth $+15 \%$ baobab $+15 \%$ butternut, $\mathrm{V} 2=22.5 \%$ sorghum $+42.5 \%$ maize $+5 \%$ grain amaranth $+15 \%$ baobab $+15 \%$ butternut, $\mathrm{V} 3=32.5 \%$ sorghum $+32.5 \%$ maize $+5 \%$ grain amaranth $+15 \%$ baobab $+15 \%$ butternut, V4 $=65 \%$ sorghum $+5 \%$ grain amaranth $+15 \%$ baobab $+15 \%$ butternut, V5 $=100 \%$ sorghum. AV $1=42.5 \%$ sorghum $+22.5 \%$ cassava $+5 \%$ chickpea $+15 \%$ baobab $+15 \%$ Orange fleshed sweet potato (OFSP), AV $2=22.5 \%$ sorghum $+42.5 \%$ cassava $+5 \%$ chickpea $+15 \%$ baobab $+15 \%$ OFSP, AV $3=32.5 \%$ sorghum $+32.5 \%$ cassava $+5 \%$ chickpea $+15 \%$ baobab $+15 \%$ OFSP, AV $4=65 \%$ sorghum $+5 \%$ chickpea $+15 \%$ baobab $+15 \%$.

\begin{tabular}{|c|c|c|c|c|c|c|c|c|c|c|}
\hline$\frac{\text { Sample }}{\text { Parameter }}$ & V1 & AV1 & $\mathrm{V} 2$ & AV2 & V3 & AV3 & V4 & AV4 & V5 & $\mathrm{p}$-value \\
\hline $\mathrm{P}$ & $0.14 \pm 0.03^{a}$ & $0.10 \pm 0.02^{a}$ & $0.14 \pm 0.02^{\mathrm{a}}$ & $0.09 \pm 0.02^{\mathrm{a}}$ & $0.16 \pm 0.05^{\mathrm{a}}$ & $0.22 \pm 0.11^{\mathrm{a}}$ & $0.13 \pm 0.02^{a}$ & $0.12 \pm 0.003^{\mathrm{a}}$ & $0.11 \pm 0.02^{a}$ & 0.091 \\
\hline $\mathrm{Zn}$ & $0.65 \pm 0.20^{\mathrm{b}, \mathrm{c}}$ & $1.00 \pm 0.03^{\mathrm{a}, \mathrm{b}}$ & $0.59 \pm 0.07^{\mathrm{c}}$ & $1.00 \pm 0.05^{\mathrm{a}, \mathrm{b}}$ & $0.62 \pm 0.12^{\mathrm{c}}$ & $1.18 \pm 0.03^{\mathrm{a}}$ & $0.88 \pm 0.84^{\mathrm{a}, \mathrm{b}}$ & $1.2 \pm 0.15^{\mathrm{a}}$ & $0.67 \pm 0.22^{\mathrm{b}, \mathrm{c}}$ & $<0.01$ \\
\hline $\mathrm{Fe}$ & $0.08 \pm 0.01^{\mathrm{a}}$ & $0.09 \pm 0.03^{\mathrm{a}}$ & $0.09 \pm 0.16^{\mathrm{a}}$ & $0.07 \pm 0.01^{\mathrm{a}}$ & $0.07 \pm 0.12^{\mathrm{a}}$ & $0.08 \pm 0.003^{a}$ & $0.08 \pm 0.07^{\mathrm{a}}$ & $0.08 \pm 0.008^{\mathrm{a}}$ & $0.07 \pm 0.02^{\mathrm{a}}$ & 0.482 \\
\hline $\mathrm{Ca}$ & $0.58 \pm 0.03^{f}$ & $1.89 \pm 0.04^{\mathrm{c}}$ & $1.90 \pm 0.04^{\mathrm{c}}$ & $4.36 \pm 0.76^{b}$ & $1.75 \pm 0.03^{c}$ & $4.73 \pm 0.23^{\mathrm{a}}$ & $1.23 \pm 0.04^{\mathrm{d}}$ & $1.29 \pm 0.13^{\mathrm{d}}$ & $0.86 \pm 0.01^{\mathrm{e}}$ & $<0.01$ \\
\hline $\mathrm{Mg}$ & $3.84 \pm 0.07^{\mathrm{a}}$ & $4.1 \pm 0.27^{\mathrm{a}, \mathrm{b}}$ & $3.84 \pm 0.09^{\mathrm{a}}$ & $3.32 \pm 0.64^{b}$ & $3.90 \pm 0.07^{\mathrm{a}}$ & $4.02 \pm 0.88^{\mathrm{a}, \mathrm{b}}$ & $3.52 \pm 0.40^{\mathrm{a}}$ & $5.11 \pm 0.16^{\mathrm{a}}$ & $3.46 \pm 0.19^{\mathrm{a}}$ & 0.02 \\
\hline
\end{tabular}

P-phosphorus; Zn-zinc; Fe-iron; Ca-calcium; Mg-magnesium. Values are means and standard deviations of triplicate determinations. Values with different superscript alphabetical letter(s) within the same column show significant differences $(\mathrm{P}<0.05)$, while values with same alphabetical letter(s) within the same column show no-significant differences among mineral composition $(\mathrm{P}<0.05)$. V5-a $100 \%$ sorghum flour was used as the control

Where -for Table IV; V1 $=42.5 \%$ sorghum $+22.5 \%$ maize $+5 \%$ grain amaranth $+15 \%$ baobab $+15 \%$ butternut, V2 $=22.5 \%$ sorghum $+42.5 \%$ maize $+5 \%$ grain amaranth $+15 \%$ baobab $+15 \%$ butternut, $\mathrm{V} 3=32.5 \%$ sorghum $+32.5 \%$ maize $+5 \%$ grain amaranth $+15 \%$ baobab $+15 \%$ butternut, V4 $=65 \%$ sorghum $+5 \%$ grain amaranth $+15 \%$ baobab $+15 \%$ butternut, V5=100\% sorghum. AV $1=42.5 \%$ sorghum $+22.5 \%$ cassava $+5 \%$ chickpea $+15 \%$ baobab $+15 \%$ Orange fleshed sweet potato (OFSP), AV2 $=22.5 \%$ sorghum $+42.5 \%$ cassava $+5 \%$ chickpea $+15 \%$ baobab $+15 \%$ OFSP, AV $3=32.5 \%$ sorghum $+32.5 \%$ cassava $+5 \%$ chickpea $+15 \%$ baobab $+15 \%$ OFSP, AV $4=65 \%$ sorghum $+5 \%$ chickpea $+15 \%$ baobab $+15 \%$. 


\section{B. Mineral concentration}

Table IV. shows the mineral contents the various composite flours. Iron and phosphorus concentrations between the sorghum composite flours were not significantly different ( $\mathrm{p}>$ 0.05). Phosphorus concentrations ranged from 0.11-0.16 $\mathrm{mg} / 100 \mathrm{~g}$ however these values were lower than those values reported by Shegro et al. [34] and Samia et al. [3]. On the other hand, there were significant differences in the zinc, calcium and magnesium concentrations. Zinc concentrations were higher in sorghum composite flours of AV1, AV2, AV3 and AV4 is attributed to the additions of OFSP and cassava because they are reported to be rich in these minerals [35]. Similarly, these OFSP and cassava based composite flours recorded a higher calcium content than maize based composite flours V1-V4. The calcium content of the OFSP -based and maize-based complementary foods support the trend previously reported that sweet potato is higher in calcium than is maize.

The magnesium concentration ranged from $3.46 \%$ to $5.11 \%$ in V5 and AV4, respectively, which values were higher than the concentrations of other minerals recorded. Fanta and Satheesh [35] reported that staple cereals are better sources of magnesium than OFSP, other roots and tubers, and this is probably why V5 (100\% sorghum flour) had a higher magnesium value than the sorghum composite flours.
Additionally, high magnesium levels is probably due to varietal and agro-ecological conditions [36].

\section{Pearson correlation between proximate composition and mineral concentration}

Pearson correlation analysis output is presented in Table V. There was significant negative correlation between crude protein and fibre $(-0.512, \mathrm{p} \leq 0.001)$, crude protein and iron ($0.386, \mathrm{p} \leq 0.047)$ whilst crude protein and magnesium had a significant positive correlation $(0.455, \mathrm{p} \leq 0.017)$ (Table V). Therefore, it is possible that some of the ingredients mixed with the sorghum to make the composite flours increased bioavailability of dietary magnesium as they are potential sources of magnesium. The inverse relationship between iron and crude protein might have implications on iron bioavailability. The correlation between ash and fats was $0.387, \mathrm{p} \leq 0.046$, whilst calcium and zinc had a correlation of $0.478, p \leq 0.012$. This could be due to the high proportion of zinc in sorghum (> $50 \mathrm{ppm}$ ) [6]. Other significant correlation includes crude protein and total carbohydrates $(-0.599, \mathrm{p} \leq$ $0.001)$, and total carbohydrates and crude fat $(-0.709, \mathrm{p} \leq$ $0.00)$. The inverse correlation between carbohydrates and crude fat could be attributed to larger proportions of fat deficient foods added to sorghum to make composite flour [37], [38].

table V: Correlation Coefficients Showing Pair-Wise Association Among Mineral Elements, Crude Protein, Ash, Crude Fibre, Crude Fat AND TOTAL CARBOHYDRATE COMPOSITION IN COMPOSITE FLOURS

\begin{tabular}{|c|c|c|c|c|c|c|c|c|c|}
\hline & \multirow{2}{*}{$\begin{array}{l}\text { Crude } \\
\text { Protein }\end{array}$} & \multirow{2}{*}{ Ash } & \multirow{2}{*}{ Crude Fibre } & \multirow{2}{*}{$\mathrm{TC}$} & \multirow{2}{*}{ Crude Fat } & \multicolumn{4}{|c|}{ Minerals } \\
\hline & & & & & & $\mathrm{P}$ & $\mathrm{Zn}$ & $\mathrm{Fe}$ & $\mathrm{Ca}$ \\
\hline Ash & $.380(0.051)$ & & & & & & & & \\
\hline Fibre & $-.512^{* *}(\mathbf{0 . 0 0 6})$ & $-.107(0.594)$ & & & & & & & \\
\hline $\mathrm{TC}$ & $-.599^{* * *}(\mathbf{0 . 0 0 1})$ & $-.087(0.685)$ & $.112(0.578)$ & & & & & & \\
\hline Fat & $.081(0.689)$ & $-.387^{*}(0.046)$ & $-.084(0.671)$ & $-.709^{* *}(0.00)$ & & & & & \\
\hline $\mathrm{P}$ & $.289(0.144)$ & $.298(0.131)$ & $-.159(0.428)$ & $-.020(0.923)$ & $-.240(0.228)$ & & & & \\
\hline $\mathrm{Zn}$ & $.169(0.399)$ & $-.015(0.942)$ & $.024(0.904)$ & $.022(0.912)$ & $-.182(0.365)$ & $.078(0.699)$ & & & \\
\hline $\mathrm{Fe}$ & $.386^{*}(0.047)$ & $.025(0.901)$ & $-.377(0.053)$ & $-.240(0.228)$ & $.067(0.739)$ & $\begin{array}{c}- \\
.071(0.725)\end{array}$ & $.242(0.223)$ & & \\
\hline $\mathrm{Ca}$ & $-.192(0.338)$ & $-.159(0.427)$ & $.028(0.889)$ & $.256(0.198)$ & $-.148(0.461)$ & $.259(0.192)$ & $.478^{*}(0.012)$ & $.012(0.951)$ & \\
\hline $\mathrm{Mg}$ & $.455^{*}(0.017)$ & $.134(0.506)$ & $-.294(0.473)$ & $-.144(0.473)$ & $-.094(0.641)$ & $.081(0.688)$ & $.367(0.059)$ & $.165(0.410)$ & $-.123(0.540)$ \\
\hline
\end{tabular}

**. Correlation is significant at the 0.01 level (2-tailed).

*. Correlation is significant at the 0.05 level (2-tailed).

Numbers in parenthesis represent $\mathrm{p}$-values for correlations made; Significant differences $(\mathrm{p}<0.05)$ are designated by bold text.

TC-total carbohydrates P-phosphorus; Zn-zinc; Fe-iron; Ca-calcium; Mg-magnesium

$V 1=42.5 \%$ sorghum $+22.5 \%$ maize $+5 \%$ grain amaranth $+15 \%$ baobab $+15 \%$ butternut, $V 2=22.5 \%$ sorghum $+42.5 \%$ maize $+5 \%$ grain amaranth $+15 \%$ baobab $+15 \%$ butternut, V3 $=32.5 \%$ sorghum $+32.5 \%$ maize $+5 \%$ grain amaranth $+15 \%$ baobab $+15 \%$ butternut, V4 $=65 \%$ sorghum $+5 \%$ grain amaranth + $15 \%$ baobab $+15 \%$ butternut, V5 $=100 \%$ sorghum. AV1 $=42.5 \%$ sorghum $+22.5 \%$ cassava $+5 \%$ chickpea $+15 \%$ baobab $+15 \%$ Orange fleshed sweet potato $($ OFSP $), A V 2=22.5 \%$ sorghum $+42.5 \%$ cassava $+5 \%$ chickpea $+15 \%$ baobab $+15 \%$ OFSP, AV3 $=32.5 \%$ sorghum $+32.5 \%$ cassava $+5 \%$ chickpea $+15 \%$ baobab $+15 \%$ OFSP, AV4 $=65 \%$ sorghum $5 \%$ chickpea $+15 \%$ baobab $+15 \%$ OFSP.

\section{CONCLUSION}

The application of food to food fortification resulted in nutrient enhanced sorghum-based composite flours with improved nutritional and physicochemical properties which are suitable for both home and industrial applications. Sorghum fortified products are highly likely to be accepted and hence should be popularized and adapted by the caregivers to enhance food and nutrition diversity. This study showed that incorporation of locally available foods to sorghum flour has the potential to improve the nutritional profile of sorghum and therefore if fully accepted by consumers would contribute to reduction of protein energy and micronutrient malnutrition among children aged 6-59 months in developing countries. 


\section{ACKNOWLEDGEMENT}

This work was funded by the United States Agency for International Development (USAID) Bureau for Food Security under Agreement \# AID-OAA-L-12-00003 as part of Feed the Future Innovation Lab for Food Processing and Post-harvest Handling and National Research Foundation Kenya Project No. 46/2018. Any opinions, findings, conclusions, or recommendations expressed here are those of the authors alone.

\section{ETHICAL STATEMENT}

Conflict of interest: The authors declare no potential conflicts of interest with respect to the research, authorship, and/or publication of this article.

Ethical Review: The study does not involve any human or animal testing.

\section{REFERENCES}

[1] S. Jood, N. Khetarpaul, and R. Goyal, "Nutrition \& Food Effect of Germination and Probiotic Fermentation on $\mathrm{pH}$, Titratable Acidity, Dietary Fibre , $\beta$-Glucan and Vitamin Content of Sorghum Based Food Mixtures," Nutrition and Food Science, vol. 2, no. 9, pp. 2-5, 2012.

[2] J. O. Anyango, H. L. De Kock, and J. R. N. Taylor, "LWT - Food Science and Technology Evaluation of the functional quality of cowpea-forti fi ed traditional African sorghum foods using instrumental and descriptive sensory analysis," LWT - Food Science and Technology, vol. 44, no. 10, pp. 2126-2133, 2011.

[3] R. Samia, E. Hagir, H. Wisal, B. Elfadi, and A. El-tinay, "Proximate composition, antinutritional factors and mineral content and availability of selected legumes and cereals grown in Sudan," Food Technology, vol. 3, no. 4, pp. 511-515, 2005.

[4] J. Awika and L. Rooney, "Sorghum phytochemicals and their potential impact on human health," Phytochemistry, vol. 1931, pp. 121-140, 2004.

[5] R. Young and P. L. Pellet, "Plant proteins in relation to human and amino acid nutrition," American Clinical Nutrition, vol. 59, pp. 1203S-1212S, 1994.

[6] T. K. Duncan, C. W. Muui, and M. M. Reuben, "Participatory identification and evaluation of sorghum (Sorghum bicolor (L.) Moench) landraces from lower eastern Kenya," African Journal of Agricultural Research and Soil Science, vol. 8, no. 36, pp. 4573-4579, 2013.

[7] P. W. Gitau, C. N. Kunyanga, G. O. Abong, J. O. Ojiem, and J. W. Muthomi, "Assessing Sensory Characteristics and Consumer Preference of Legume-Cereal-Root Based Porridges in Nandi County," Food Quality, pp. 1-8, 2019.

[8] C. Onyango and G. W. Wanjala, "Quality of porridge from sub-Saharan Africa evaluated using instrumental techniques and descriptive sensory lexicon . Part 2: Thin porridge," African Journal of Food Science, vol. 12, no. 5, pp. 104-114, 2018.

[9] W. G. Wanjala, A. Onyango, M. Makayoto, and C. Onyango, "Indigenous technical knowledge and formulations of thick (ugali) and thin (uji) porridges consumed in Kenya," African Journal of Food Science, vol. 10, no. 12, pp. 385-396, 2016.

[10] C. Onyango, M. W. Okoth, and S. K. Mbugua, "The pasting behaviour of lactic-fermented and dried uji ( an East African sour porridge )," Journal of the Science ofFood and Agriculture, vol. 83, no. July, pp. 1412-1418, 2003.

[11] K. Joyce, A. Loy, and F. B. Lukwago, "Nutritional and sensory properties of high energy/nutrient dense composite flour porridges from germinated maize and roasted beans for child-weaning in developing countries: a case for Uganda.," Ecology of Food and Nutrition, vol. 45, pp. 279-294, 2006.

[12] O. S. Ijarotimi and O. A. Ayantokun, "Nutritional Composition, Sensory and Biological Evaluation of A Potential Weaning Diet from Low Cost Food Materials (Sorghum bicolor and Cajanus cajan)," Journal of Food Technology, vol. 4, no. 3. pp. 178-184, 2006.

[13] N. Malleshi, M. . Daodu, and A. Chandrasekhar, "Development of weaning food formulations based on malting and roller drying of sorghum and cowpea," International Journal of Food Science and Technology, vol. 24, p. 511_519, 1989.

[14] O. A. Akande, D. Nakimbugwe, and I. M. Mukisa, "Optimization of extrusion conditions for the production of instant grain amaranth- - based porridge flour," Food Science and Nutrition, no. July, pp. 1205-1214, 2017.

[15] J. Elisa, N. Tharise, and M. Nurminah, "Evaluation of physico-chemical and functional properties of composite flour from cassava, rice, potato , soybean and xanthan gum as alternative of wheat flour Evaluation of physico-chemical and functional properties of composite flour from cassava , ric," International Food Research Journal, vol. 21, no. 4, pp. 1641-1649, 2016.

[16] M. Kadam, R. Salve, Z. Mehrajfatema, and S. More, "Development and Evaluation of Composite Flour for Missi roti / chapatti," Food Processing and Technology, vol. 3, no. 1, pp. 1-7, 2012.

[17] P. Mounjouenpou et al., "Effect of fortification with baobab ( Adansonia digitata L .) pulp flour on sensorial acceptability and nutrient composition of rice cookies Effect of fortification with baobab ( Adansonia digitata L .) pulp flour on sensorial acceptability and nutrient composition of rice cookies," Scientific African, vol. 1, no. February 2020, p. e00002, 2018.

[18] Institute of Medicine of the National Academics, Dietary Reference Intakes. The Essential Guide to Nutrient Requirements. 2006.

[19] AOAC, Official Methods of Analysis of AOAC International, 15th ed. Gaithersbury, Maryland, USA: AOAC Publishers. 1990.

[20] G. A. Tumuhimbise, G. Tumwine, and W. Kyamuhangire, "Amaranth Leaves and Skimmed Milk Powders Improve the Nutritional, Functional, Physico-Chemical and Sensory Properties of Orange Fleshed Sweet Potato Flour," 2019.

[21] C. Anino, A. N. Onyango, S. Imathiu, J. Maina, and F. Onyangore, "Chemical composition of the seed and 'milk' of three common bean (Phaseolus vulgaris L) varieties," Journal of Food Measurement and Characterization, vol. 13, no. 2, pp. 1242-1249, 2019.

[22] J. R. Okalebo, K. W. Gathua, and Paul L. Woomer, "Laboratory Methods of Soil and Plant Analysis," 2002.

[23] N. Murakatete, Y. F. Hua, and P. C. Irakoze, "Characterization of Ready to eat composite porridge flours made by soy-maize-sorghum-wheat extrudion cooking process.," Pakistan Journal of Nutrition, vol. 2, pp. 171-178, 2010.

[24] A. C. Codex, "Codex Alimentarius Commission. Guidelines on formulated complementary foods for older infants and young children.," 1991

[25] M. Mabelebele, M. Siwela, R. M. Gous, and P. A. Iji, "Chemical composition and nutritive value of South African sorghum varieties as feed for broiler chickens," South African Journal of Animal Sciences, vol. 45, no. 2, pp. 206-213, 2015.

[26] M. H. Dicko, H. Gruppen, A. S. Traore, A. G. J. Voragen, and W. J. H. Van Berkel, "Sorghum grain as human food in Africa: relevance of starch content and amylase activities," African Journal of Biotechnology, vol. 5, no. 5, pp. 384-395, 2006.

[27] K. G. Duodu, J. R. N. Taylor, P. S. Belton, and B. R. Hamaker, "Factors affecting sorghum protein digestibility," Journal of Cereal Science, vol. 38, no. 2, pp. 117-131, 2003.

[28] C. Chiremba, J. R. N. Taylor, and K. G. Duodu, "Phenolic content, antioxidant activity, and consumer acceptability of sorghum cookies," Cereal Chemistry, vol. 86, no. 5, pp. 590-594, 2009.

[29] H. Twinomuhwezi, C. G. Awuchi, and M. Rachael, "Comparative Study of the Proximate Composition and Functional Properties of Composite Flours of Amaranth, Rice, Millet, and Soybean," American Journal of of Food Science and Nutrition, vol. 6, no. March, pp. 6-19, 2020.

[30] A. G. Samarth, D. R. More, and H. Imran, "Studies on physico-chemical properties and nutritional profile of sweet sorghum," International Journal of Chemical Studies, vol. 6, no. 2, pp. 2826-2828, 2018.

[31] P. K. Marete and M. Mwasaru, "Nutritional composition of Kenyan sorghum-pigeon pea instant," Journal of Agriculture, Science and Technology (JAGST), vol. 17, no. February, pp. 1-13, 2016.

[32] F. K. Amagloh and J. Coad, "Orange-fleshed sweet potato-based infant food is a better source of dietary vitamin A than a maize - legume blend as complementary food," vol. 35, no. 1, pp. 51-59, 2014.

[33] B. Daelmans, J. Martines, and R. Saadeh, "Conclusions of the Global Consultation on Complementary Feeding," Food and Nutrition Bulletin, vol. 24, no. 1, pp. 126-129, 2003.

[34] A. Shegro, N. G. Shargie, A. van Biljon, and M. T. Labuschagne, "Diversity in Starch, Protein and Mineral Composition of Sorghum 
Landrace Accessions from Ethiopia," Journal of Crop Science and Biotechnology, vol. 16, no. 1, pp. 83-83, 2013.

[35] S. W. Fanta and N. Satheesh, "Review on nutritional composition of orange - fleshed sweet potato and its role in management of vitamin A deficiency," Food Science and Nutrition, no. January, pp. 1920-1945, 2019.

[36] E. Dako, N. Retta, and G. Desse, "Comparison of Three Sweet Potato (Ipomoea Batatas (L.) Lam)Varieties on Nutritional and Anti-Nutritional Factors," Global Journal of Science Frontier Research: D Agriculture and Veterinary., vol. 16, no. 4, pp. 1-11, 2016.

[37] FAO, "Sorghum and Millets in Human Nutrition," Rome, 1995.

[38] I. Proietti, C. Frazzoli, and A. Mantovani, "Exploiting Nutritional Value of Staple Foods in the World's Semi-Arid Areas: Risks, Benefits, Challenges and Opportunities of Sorghum," Healthcare, vol. 3, no. 2, pp. 172-193, 2015. 